\title{
Prevalence and Intensity of Opisthorchis viverrini Metacercarial Infection in Fish from Phnom Penh, Takeo, and Kandal Provinces, Cambodia
}

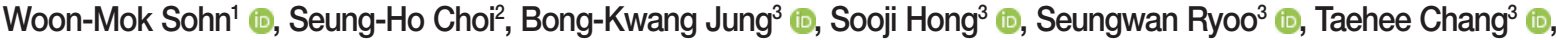

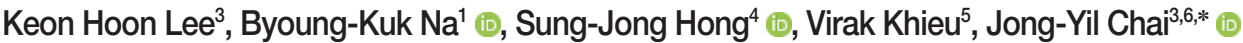 \\ 'Department of Parasitology and Tropical Medicine, and Institute of Health Sciences, Gyeongsang National University College of Medicine, Jinju \\ 52727, Korea; '2Society of Korean Naturalist, Institute of Ecology and Conservation, Yangpyeong 12563, Korea; ${ }^{3}$ Institute of Parasitic Diseases, \\ Korea Association of Health Promotion, Seoul 07649, Korea; ${ }^{4}$ Convergence Research Center for Insect Vectors, Incheon National University, \\ Incheon 22012, Korea; ${ }^{5}$ National Center for Parasitology, Entomology and Malaria Control, Phnom Penh, Cambodia; ${ }^{6}$ Department of Tropical \\ Medicine and Parasitology, Seoul National University College of Medicine, Seoul 03080, Korea
}

\begin{abstract}
The prevalence and intensity of Opisthorchis viverrini metacercariae (OvMc) were investigated in fish from 3 southern administrative regions along the Mekong River in Cambodia, i.e., Phnom Penh, Takeo, and Kandal Provinces from 2017 to 2020. A total of 295 freshwater fish ( 24 species) were transported to our laboratory with ice and examined using the artificial digestion method. In Phnom Penh, among 4 fish species positive for OvMc, 9 (23.7\%) of 38 specimens examined were infected, and their intensity of infection averaged 4.3 metacercariae per infected fish. In Takeo Province, among 10 fish species positive for OvMc, 24 (38.1\%) out of 63 fish examined were infected, and their intensity of infection was av. 14.4 metacercariae per infected fish. In particular, all of 3 Osteochilus schlegelii fish examined were infected, and their infection intensity was high, 34.7 metacercariae per fish. In Kandal Province, among 6 fish species positive for OvMc, 46 (90.2\%) out of 51 specimens examined were infected, and their infection intensity was 24.0 metacercaraie per infected fish. All fish of Systomus orphoides $(n=17)$, Barbonymus altus $(n=14)$, and Rasbora aurotaenia $(n=2)$ were infected, and their intensity of infection averaged 37.7, 21.6, and 18.5 metacercariae per fish, respectively. Metacercariae of Haplochis yokogawai, Haplorchis taichui, and Centrocestus formosanus were detected in fish from Takeo and Kandal Provinces. From these results, it has been confirmed that a variety of fish species from Phnom Penh, Takeo, and Kandal Provinces are commonly infected with OvMc, and preventive measures to avoid human O. viverrini infection should be performed in Cambodia.
\end{abstract}

Key words: Opisthorchis viverrini metacercaria, freshwater fish, Phnom Penh, Takeo Province, Kandal Province, Cambodia

Fishborne zoonotic trematodes (FZT), including Opisthorchis viverrini, are public health problems in Southeast Asian countries, i.e., Thailand, Lao People's Democratic Republic (Lao PDR), Vietnam, and Cambodia. O. viverrini can provoke remarkable pathology and morbidity, such as cholangiocarcinoma, among residents of riverside endemic areas [1,2]. Infections with this liver fluke in humans are usually caused by habitual consumption of raw freshwater fish containing metacercariae. This infection is highly prevalent among riparian populations having the food habit of eating raw fish. Many riverside areas along

- Received 9 October 2021, revised 11 October 2021, accepted 11 October 2021.

*Corresponding author (cjy@snu.ac.kr)

(c) 2021, Korean Society for Parasitology and Tropical Medicine

This is an Open Access article distributed under the terms of the Creative Commons Attribution Non-Commercial License (https://creativecommons.org/licenses/by-nc/4.0) which permits unrestricted non-commercial use, distribution, and reproduction in any medium, provided the original work is properly cited. the Mekong river in Vietnam, Lao PDR, Thailand, and Cambodia are known to be highly endemic with $O$. viverrini infection [3-10].

Cambodia is administratively divided into 25 provinces, including the capital, i.e., Phnom Penh Municipality (= Phnom Penh). Among these administrative localities, Phnom Penh, Takeo, and Kandal Provinces are located along the Mekong River in the southern part of Cambodia. Kandal Province completely surrounds the capital city, Phnom Penh [11]. On the other hand, a lot of Cambodian people are infected with various species of helminths, especially, soil-transmitted nematodes and FZTs, including O. viverrini [12-14]. In the Project of Korea-Cambodia International Collaboration on Intestinal Parasite Control in Cambodia [15,16], it has been repeatedly reported that infections with $O$. viverrini are prevalent in several localities along the Mekong River in Cambodia [8-10,15]. 
Khieu et al. [10] broadly analyzed the information regarding the epidemiological situation of O. viverrini infection in Cambodia.

Several workers previously reported the infection status of zoonotic trematode metacercariae (ZTM), in particular, O. viverrini, in freshwater fish purchased from Phnom Penh, Pursat, Takeo, and Kratie Provinces [8,9,17-20]. However, studies on the infection status of freshwater fish with ZTM need to be continuously performed in different localities of Cambodia. Therefore, in this study, we surveyed the prevalence and intensity of $O$. viverrini metacercarial infection in fish purchased from local markets in 3 southern administrative regions, i.e., Phnom Penh, Takeo, and Kandal Provinces.

We purchased a total of 295 fish specimens (24 species) from local markets in 3 southern regions, i.e., Phnom Penh (86 fish in 8 species in May 2018), Takeo Province (99 fish in 16 species in November 2017), and Kandal Province (110 fish in 13 species in January-February 2020), Cambodia. The collected fish were transported to the Department of Parasitology and Tropical Medicine, Gyeongsang National University College of Medicine, Jinju, Korea with ice. The fish species were identified with the aid of the FishBase website (http://www.fishbase.org/ search.php) and by the help of a Korean ichthyologist (Choi $\mathrm{SH})$. Individual fish was finely ground in a mortar with a pestle, the ground fish meat was mixed with artificial gastric juice, and the mixture was incubated at $36^{\circ} \mathrm{C}$ for about $2 \mathrm{hr}$. The digested material was filtered through a $1 \times 1 \mathrm{~mm}$ mesh, and washed with $0.85 \%$ saline until the supernatant became clear. The sediment was carefully examined for metacercariae under a stereomicroscope. The metacercariae of each species (only ZTM) were collected viewing from the general features and were counted to get hold of the prevalence (\%) and intensity of infection (no. of ZTM per fish infected) by fish species. The metacercariae of 175-210 (av. 195) ×138-163 (150) $50 \mu \mathrm{m}$ in size with characteristic morphologies of the oral and ventral suckers and the excretory bladder were regarded as the O. viverrini metacercaria (OvMc) (Fig. 1A).

A total of 86 fish specimens of 8 species were purchased from Phnom Penh in May 2018. The fish species (no. of fish) included Anabas testudineus ( $\mathrm{n}=20)$, Channa striata (18), Henicorhynchus lobatus (13), Hypsibarbus wetmorei (10), Monopterus albus (10), Barbonymus altus (9), Labeo chrysophekadion (5), and Puntioplites proctozysron (1). The results revealed that OvMc were positive in 9 (23.7\%) out of 38 fish, and their infection intensity was av. 4.3 metacercariae per infected fish (Table 1).

In Takeo Province, total 99 fish specimens of 16 species were examined in November 2017. The fish species (no. of fish) included P. proctozysron ( $\mathrm{n}=18)$, Cirrhinus julieni (15), A. testudineus (12), M. albus (11), Barbonymus gonionotus (8), Syncrossus helodes (8), Cirrhinus molitorella (7), C. striata (7), Osteochilus schlegelii (3), B. altus (2), Osteochilus microcephalus (2), Yasuhikotakia modesta (2), L. chrysophekadion (1), Systomus orphoides (1), Puntius sp. (1), and Pristolepis fasciata (1). OvMc were detected in 24 (38.1\%) out of 63 fish, and their infection intensity averaged 14.4 per fish infected. Especially, in the case of $O$. schlegelii fish, all 3 fish specimens examined were infected with OvMc, and their infection intensity was av. 34.7 metacercarae per infected fish (Table 2).
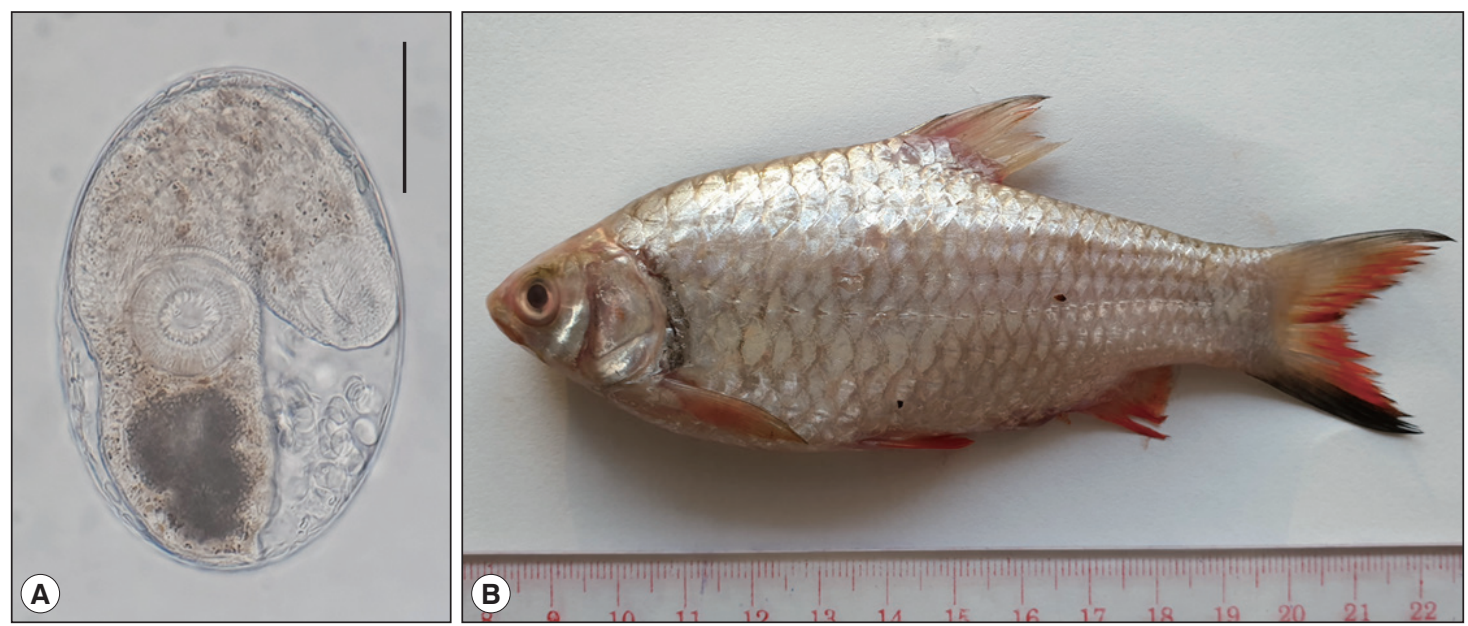

Fig. 1. (A) Metacercaria of Opisthorchis viverrini isolated from Systomus orphoides fish from Kandal Province, Cambodia. Scale bar $=50$ um. (B) S. orphoides, a susceptible fish host for O. viverrini, purchased from a local market in Kandal Province, Cambodia. 
In Kandal Province, total 110 fish specimens of 13 species were purchased in January and February 2020. The fish species (no. of fish) included Labiobarbus lineatus $(\mathrm{n}=20)$, S. orphoides (17), B. altus (14), Leptobarbus rubripinna (11), L. chrysophekadion (10), A. testudineus (10), Oxyeleotris marmorata (8), Cyclocheilichthys enoplus (6), O. schlegelii (6), B. gonionotus (2), P. proctozysron (2), Cyclocheilichthys apogon (2), and Rasbora aurotaenia (2). OvMc were detected in 46 (90.2\%) out of 51 fish, and their infection intensity averaged 24.0 metacercariae per infected fish. Especially, in 3 fish species, S. orphoides $(n=17)$ (Fig. 1B), B. altus $(\mathrm{n}=14)$, and $R$. aurotaenia $(\mathrm{n}=2)$, all examined specimens were infected with OvMc, and their infection intensity averaged 37.7, 21.6, and 18.5 metacercariae per infected fish, respectively (Table 3).

A few other ZTM that belong to the family Heterophyidae or the Echinostomatidae were also detected in this study. In Takeo

Table 1. Infection status of Opisthorchis viverrini metacercariae (OvMc) by the species of fish from Phnom Penh, Cambodia

\begin{tabular}{lcccc}
\hline \multirow{2}{*}{ Fish species exmined } & No. of fish examined & No. (\%) of fish infected & \multicolumn{2}{c}{ No. of OvMc detected } \\
\cline { 3 - 5 } & 18 & $4(22.2)$ & $2-13$ & Range \\
\hline Channa striata & 10 & $2(20.0)$ & - & 1.0 \\
Hypsibarbus wetmorei & 9 & $2(22.2)$ & - & 1.0 \\
Barbonymus altus & 1 & $1(100)$ & $1-13$ & 8.0 \\
Puntioplites proctozysron & 38 & $9(23.7)$ & 4.3 \\
Total & & & - & 1.0 \\
\hline
\end{tabular}

Other fish species examined, including A. testudineus ( $\mathrm{n}=20)$, Henicorhynchus lobatus (13), Monopterus albus (10), and L. chrysophekadion (5), gave negative results.

Table 2. Infection status of Opisthorchis viverrini metacercariae (OvMc) by the species of fish from Takeo Province, Cambodia

\begin{tabular}{lcccc}
\hline & & & & \multicolumn{2}{c}{ No. of OvMc detected } \\
\cline { 3 - 4 } Fish species exmined & No. of fish examined & No. (\%) of fish infected & Range & 18.9 \\
\cline { 3 - 4 } Puntioplites proctozysron & 18 & $10(55.6)$ & $1-86$ & - \\
Cirrhinus julieni & 15 & $1(6.7)$ & - & 2.0 \\
Barbonymus gonionotus & 8 & $1(12.5)$ & $1-6$ & 2.8 \\
Cirrhinus molitorella & 7 & $4(57.1)$ & - & 1.0 \\
Channa striata & 7 & $1(14.3)$ & $15-69$ & 34.7 \\
Osteochilus schlegelii & 3 & $3(100)$ & - & 4.0 \\
Barbonymus altus & 2 & $1(50.0)$ & - & 12.0 \\
Labeo chrysophekadion & 1 & $1(100)$ & - & 15.0 \\
Systomus orphoides & 1 & $1(100)$ & $1-86$ & 7.0 \\
Puntius sp. & 1 & $1(100)$ & $24(38.1)$ & 14.4 \\
Total & 63 & & \\
\hline
\end{tabular}

Other species of fish examined, including Anabas testudineus (12), Monopterus albus (11), Syncrossus helodes (8), Osteochilus microcephalus (2), Yasuhikotakia modesta (2), and Pristolepis fasciata (1), gave negative results.

Table 3. Infection status of Opisthorchis viverrini metacercariae (OvMc) by the species of fish from Kandal Province, Cambodia

\begin{tabular}{lcccc}
\hline \multirow{2}{*}{ Fish species exmined } & No. of fish examined & No. (\%) of fish infected & \multicolumn{2}{c}{ No. of OvMc detected } \\
\cline { 4 - 5 } & 17 & $17(100)$ & $2-92$ & 37.7 \\
Systomus orphoides & 14 & $14(100)$ & $1-90$ & 21.6 \\
Barbonymus altus & 10 & $7(70.0)$ & $1-21$ & 6.1 \\
Labeo chrysophekadion & 6 & $5(83.3)$ & $2-30$ & 15.2 \\
Osteochilus schlegelii & 2 & $1(50.0)$ & - & 7.0 \\
Puntioplites proctozysron & 2 & $2(100)$ & $3-34$ & 18.5 \\
Rasbora aurotaenia & 51 & $46(90.2)$ & $1-92$ & 24.0 \\
\hline Total & & & & \\
\hline
\end{tabular}

Other species of fish examined, including Labiobarbus lineatus $(n=20)$, Leptobarbus rubripinna (11), A. testudineus (10), Oxyeleotris marmorata (8), Cyclocheilichthys enoplus (6), B. gonionotus (2), and Cyclocheilichthys apogon (2), gave negative results. 
Province, the metacercariae of $H$. yokogawai (HyMc) were detected in 2 fish species, i.e., P. proctozysron $(7 / 18 ; 38.9 \%)$ and $C$. julieni $(3 / 15 ; 20.0 \%)$ with their infection intensity of 102.6 and 11.3 per fish, respectively. The HyMc were also found in Kandal Province in 48 (57.1\%) out of 84 fish (9 species) examined, and their infection intensity averaged 65.9 per infected fish. In fish from Kandal Province, 2 other species of heterophyid metacercariae were detected; Haplorchis taichui metacercariae $(\mathrm{n}=30)$ in $1(5.0 \%)$ of 20 L. lineatus, and Centrocestus formosanus metacercariae $(\mathrm{n}=6)$ in $2(11.8 \%)$ of 17 S. orphoides. An unidentified species of echinostome metacercariae was detected in $6(75.0 \%)$ out of 8 O. marmorata (the marble goby), and their infection intensity averaged 8 (1-21) metacercariae per fish.

In our study, the prevalence and intensity of OvMc in fish were relatively low compared with our previous studies (by the Korean team) in Cambodia $[8,9,20]$, with the exception of Kandal Province which revealed higher values. The endemicity indices of OvMc (mean no. of metacercariae per fish x prevalence/100) in this study were 1.0 (Phnom Penh), 5.5 (Takeo), and 21.6 (Kandal). Chai et al. [20] detected a total of 690 OvMc (18.6 metacercariae per fish) in 37 (50.0\%) out of 74 fish examined in Phnom Penh, where the endemicity index was 9.3. Sohn et al. [9] detected a total of 50 OvMc (10.0/fish) in $5(100 \%)$ of 5 P. proctozysron from Takeo province, and the endemicity index was 10.0. Sohn et al. [8] also detected a total of 367 OvMc (19.3/fish) in 19 (63.3\%) out of 30 fish examined in Kratie Province, and the endemicity index was 12.2.

In Kandal and Takeo Provinces, Touch et al. [18] reported lower prevalence and lower intensity of OvMc; they detected a total of 789 OvMc (4.8/fish) in 163 (17.5\%) out of 929 fish, and the endemicity index was only 0.8 . From the present and previous studies, we could confirm that the endemicity of OvMc has been continuously maintained in southern localities of Cambodia along the Mekong River, i.e., Phnom Penh, Takeo, Kratie, and Kandal Provinces. However, the endemicity was more or less different by survey localities. The endemicity index of OvMc was the highest (21.6) in Kandal Province as depicted in this study.

A lot of fish species have been found to be infected with OvMc in Cambodia. In this study, OvMc were detected in 12 fish species, namely, B. altus, B. gonionotus, C. striata, C. julieni, C. molitorella, H. wetmorei, L. chrysophekadion, O. schlegelii, P. proctozysron, Puntius sp., R. aurotaenia, and S. orphoides. Touch et al. [18] reported 10 infected fish species, i.e., Barbodes altus (= Barbo- nymus altus), Cyclocheilichthys apagon, Cyclocheilichthys enoplos, Hampala dispar, Hampala macrolepidota, Henicorhynchus siamensis, P. proctozysron, Puntius brevis, S. orphoides, and Thynnichthys thynnoides, from the border of Kandal and Takeo Provinces. Sohn et al. [9] obtained OvMc in P. proctozysron from Takeo Province, and Sohn et al. [8] found OvMc in 3 fish species, i.e., P. proctozysron, Puntius orphoides (=Systomus orphoides) and $L$. chrysophekadion, from Kratie Province. Chai et al. [20] detected OvMc in 11 fish species from Phnom Penh, i.e., B. altus, Barbonymus schwanefeldi, C. jullieni, Cirrhinus microlepis, Henicorhynchus lobatus, H. siamensis, L. chrysophekadion, Luciosoma bleekeri, Osteochilus melanopleurus, P. proctozysron, and T. thynnoides, and 2 fish species from Pursat Province, i.e., P. falcifer and Henicorhynchus lineatus. Summarizing these results, a total of 20 fish species, including B. altus, B. schwanefeldi, C. jullieni, C. microlepis, C. apagon, C. enoplos, H. dispar, H. macrolepidota, H. lineatus, H. lobatus, H. siamensis, L. chrysophekadion, L. bleekeri, O. melanopleurus, O. schlegelii, R. aurotaenia, P. proctozysron, P. brevis, $S$. orphoides, and T. thynnoides, could be listed as the second intermediate hosts for O. viverrini in Cambodia $[8,9,18-20]$.

In our study, 4 species of ZTM, including O. viverrini, $H$. yokogawai, H. taichui, and C. formosanus, were detected. In previous studies [8,9,17-20], total 5 species, including O. viverrini, H. yokogawai, H. pumilio, C. formosanus, and Proceronum sp., were detected in several localities of Cambodia. For example, all 5 species of ZTM were detected in Pursat Province [20], and 2 species, $O$. viverrini and $H$. yokogawai metacercariae, were found in Phnom Penh, Takeo, and Kratie Provinces $[8,9,20]$. In addition, in Phnom Penh, 2 other heterophyid species metacercariae were detected in largescale mullets, Chelon macrolepis; their adult flukes recovered from experimental hamsters were identified as Stellantchasmus falcatus and Pygidiopsis cambodiensis (Digenea: Heterophyidae) [21,22].

Conclusively, it has been confirmed in this study that OvMc are more or less prevalent in a variety of fish species commercially available in Phnom Penh, Takeo, and Kandal Provinces, Cambodia along the Mekong River. However, with the exception of Kandal Province, their endemicity was not so high compared with our previous reports in Cambodia. There were some limitations in this study, such as a small number of fish specimens and a small number of fish species examined.

\section{ACKNOWLEDGMENTS}

We thank Jung-A Kim and Hee-Ju Kim in the Department of 
Parasitology, Gyeongsang National University College of Medicine, Jinju, Korea, for their help in fish examinations. We also thank the staff of the Korea Association of Health Promotion, Seoul, Republic of Korea, who participated in the Korea-Cambodia Cooperation Project on Parasite Control in Cambodia (2017, 2018, and 2020).

\section{CONFLICT OF INTEREST}

The authors declare that they have no conflict of interest related with this article.

\section{REFERENCES}

1. Chai JY, Murrell KD, Lymbery AJ. Fish-borne parasitic zoonoses: status and issues. Int J Parasitol 2005; 35: 1233-1254. https://doi. org/10.1016/j.ijpara.2005.07.013

2. Andrews RH, Sithithawarn P, Petney TN. Opisthorchis viverrini: an underestimated parasite in world health. Trends Parasitol 2008; 24: 497-501. https://doi.org/10.1016/j.pt.2008.08.011

3. Radomyos B, Wongsaroy T, Wilairatana P, Radomyos P, Praevanich $R$, Meesomboon V, Jongsuksuntikul P. Opisthorchiasis and intestinal fluke infections in northern Thailand. Southeast Asian J Trop Med Public Health 1998; 29: 123-127.

4. Chai JY, Park JH, Han ET, Guk SM, Shin EH, Lin A, Kim JL, Sohn WM, Yong TS, Eom KS, Min DY, Hoang EH, Phommasack B, Insisienmay B, Rim HJ. Mixed infections with Opisthorchis viverrini and intestinal flukes in residents of Vientiane Municipality and Saravane Province in Laos. J Helminthol 2005; 79: 1-8. https:// doi.org/10.1079/JOH2005302

5. Chai JY, Han ET, Shin EH, Sohn WM, Yong TS, Eom KS, Min DY, Um JY, Park MS, Hoang EH, Phommasack B, Insisienmay B, Lee SH, Rim HJ. High prevalence of Haplorchis taichui, Prosthodendrium molenkampi, and other helminth infections among people in Khammouane Province, Lao PDR. Korean J Parasitol 2009; 47: 243-247. https://doi.org/10.3347/kjp.2009.47.3.243

6. Dung DT, De NV, Waikagul J, Dalsgaard A, Chai JY, Sohn WM, Murrell KD. Fishborne intestinal zoonotic trematodiasis, Vietnam. Emerg Infect Dis 2007; 13: 1828-1833. https://doi.org/10.3201/ eid1312.070554

7. De NV, Le TH. Human infections of fish-borne trematodes in Vietnam: prevalence and molecular specific identification at an endemic commune in Nam Dinh province. Exp Parasitol 2011; 129: 355361. https://doi.org/10.1016/j.exppara.2011.09.005

8. Sohn WM, Yong TS, Eom KS, Pyo, KH, Lee, MY, Lim HM, Choe SJ, Jeong HG, Sinuon M, Socheat D, Chai JY. Prevalence of Opisthorchis viverrini infection in humans and fish in Kratie Province, Cambodia. Acta Trop 2012; 124: 215-220. https://doi.org/10. 1016/j.actatropica.2012.08.011

9. Sohn WM, Shin EH, Yong TS, Eom KS, Jeong HG, Sinuon M, So- cheat D, Chai JY. Adult Opisthorchis viverrini flukes in humans, Takeo, Cambodia. Emerg Infect Dis 2011; 17: 1302-1304. https:// doi.org/10.3201/eid1707.102071

10. Khieu V, Fürst T, Miyamoto K, Yong TS, Chai JY, Huy R, Muth S, Odermatt $\mathrm{P}$. Is Opisthorchis viverrini emerging in Cambodia? Adv Parasitol 2019; 103: 31-73. https://doi.org/10.1016/bs.apar.2019. 02.002 .

11. Cambodia in Wikipedia-The free encyclopedia. http://en.wikipedia. org

12. Stich AHR, Biays S, Odermatt P, Men C, Saem C, Sokha K, Ly CS, Legros P, Philips M, Lormand JD, Tanner M. Foci of Schistosoma mekongi, northern Cambodia: II. Distribution of infection and morbidity. Trop Med Int Health 1999; 4: 674-685. https://doi.org/ 10.1046/j.1365-3156.1999.00474.x

13. Lee KJ, Bae YT, Kim DH, Deung YK, Ryang YS, Kim HJ, Im KI, Yong TS. Status of intestinal parasites infection among primary school children in Kampongcham, Cambodia. Korean J Parasitol 2002; 40: 153-155. http://dx.doi.org/10.3347/kjp.2002.40.3.153

14. Sinuon M, Anantaphruti MT, Socheat D. Intestinal helminthic infections in school children in Cambodia. Southeast Asian J Trop Med Pub Health 2003; 34: 254-258.

15. Yong TS, Shin EH, Chai JY, Sohn WM, Eom KS, Lee DM, Park K, Jeong HG, Hoang EH, Lee YH, Woo HJ, Lee JH, Kang SI, Cha JK, Lee $\mathrm{KH}$, Yoon $\mathrm{CH}$, Sinuon M, Socheat D. High prevalence of $\mathrm{Op}$ isthorchis viverrini infection in a riparian population in Takeo Province, Cambodia. Korean J Parasitol 2012; 50: 173-176. https://doi. org/10.3347/kjp.2012.50.2.173

16. Yong TS, Chai JY, Sohn WM, Eom KS, Jeong HG, Hoang EH, Yoon $\mathrm{CH}$, Jung BK, Lee SH, Sinuon M, Socheat D. Prevalence of intestinal helminths among inhabitants of Cambodia (2006-2011). Korean J Parasitol 2014; 52: 661-666. https://doi.org/10.3347/kjp.2014. 52.6 .661

17. Miyamoto K, Kirinoki M, Matsuda H, Hayashi N, Chigusa Y, Sinuon M, Chuor CM, Kitikoon V. Field survey focused on Opisthorchis viverrini infection in five provinces of Cambodia. Parasitol Int 2014; 63: 366-373. https://doi.org/10.1016/j.parint.2013.12.003

18. Touch S, Komalamisra C, Radomyos P, Waikagul J. Discovery of Opisthorchis viverrini metacercariae in freshwater fish in southern Cambodia. Acta Trop 2009; 111: 108-113. https://doi.org/10.1016/ j.actatropica.2009.03.002

19. Touch S, Yoonuan T, Nuamtanong S, Homsuwan N, Phuphisut O, Thaenkham U, Waikagul J. Seasonal variation of Opisthorchis viverrini metacercarial infection in cyprinid fish from Southern Cambodia. J Trop Med Parasitol 2013; 36: 1-7.

20. Chai JY, Sohn WM, Na BK, Yong TS, Eom KS, Yoon CH, Hoang $\mathrm{EH}$, Jeoung $\mathrm{HG}$, Socheat D. Zoonotic trematode metacercariae in fish from Phnom Penh and Pursat, Cambodia. Korean J Parasitol 2014; 52: 35-40. https://doi.org/10.3347/kjp.2014.52.1.35

21. Chai JY, Sohn WM, Na BK, Jeoung HG, Sinuon M, Socheat D. Stellantchasmus falcatus (Digenea: Heterophyidae) in Cambodia: discovery of metacercariae in mullets and recovery of adult flukes in an experimental hamster. Korean J Parasitol 2016; 54: 537-541. https://doi.org/10.3347/kjp.2016.54.4.537 
22. Sohn WM, Kim DG, Jung BK, Cho J, Chai JY. Pygidiopsis cambodiensis n. sp. (Digenea: Heterophyidae) from experimental hamsters infected with metacercariae in mullets from Cambodia.
Parasitol Res 2016; 115: 123-130. https://doi.org/10.1007/s00436015-4727-1 